\title{
Orisinalistas Teknologi Pengerjaan Kayu pada Pemugaran BCBBK Ditinjau dari Perspektif Ilmu Pemesinan Kayu
}

\author{
Oleh \\ Ir. Yustinus Suranto, M.P \\ E-mail: surantoyustinus@yahoo.com \\ Dosen Fakultas Kehutanan Universitas Gadjah Mada, Yogyakarta
}

Tulisan ilmiah ini akan diwujudkan dengan sistematika yang tersusun atas lima sub-bab. Pertama, pengerjaan kayu dan pemesinan kayu sebagai terminologi. Kedua, analisis pemotongan kayu di dalam penggunaan alat tradisional dan alat moderen. Ketiga, pengaruh pemesinan kayu terhadap kayu. Keempat, Teknologi pengerjaan kayu secara tradisional pada BCB sebagai keniscayaan. Kelima, implikasi dan konsekuensi. Masingmasing sub-bab ini akan disajikan dalam uraian berikut.

\section{Pengerjaan kayu dan pemesinan} kayu sebagai terminologi

Pengerjaan Kayu dan Pemesinan Kayu merupakan dua terminologi yang pada saat ini saling dipertukarkan penggunaannya. Sikap untuk saling mempertukarkan penggunaaan kedua istilah tersebut, tidak hanya dilakukan oleh masyarakat awam, tetapi juga dilakukan oleh komunitas masyarakat yang berkiprah dalam teknologi perkayuan. Komunitas masyarakat tersebut berasumsi, bahwa keduanya dianggap bersinonim. Dengan kata lain, kedua terminologi itu dianggap memiliki arti yang sama. Di dalam kesamaan arti itu, Pengerjaan Kayu atau Pemesinan Kayu dimengerti sebagai suatu proses untuk menginteraksikan antara kayu sebagai benda kerja dengan alat potong, yang penginteraksian itu sedemikian rupa, sehingga benda kerja kayu tersebut itu pada akhir proses interaksi itu akan memiliki bentuk, ukuran, dimensi, presisi dan tingkat kehalusan tertentu pada permukaannya sebagai hasil proses pemotongan tersebut.

Untuk memperkaya makna yang dikandung oleh masingmasing terminologi itu, penulis melalui tulisan ini mengusulkan untuk membedakan penggunaan masing-masing terminologi tersebut. Bagi penulis, terminologi Pengerjaan Kayu dapat diberi arti sebagai suatu proses untuk menginteraksikan antara kayu sebagai benda kerja dengan alat potong, yang sumber daya atau penggerak bagi alat potong itu berasal dari tenaga kerja atau orang yang mengerjakannya, sedemikian rupa sehingga benda kerja kayu tersebut itu pada akhirnya akan memiliki bentuk, ukuran, dimensi, presisi dan tingkat kehalusan tertentu pada permukaannya sebagai hasil proses pengerjaan tersebut. Sementara itu, Pemesinan Kayu dapat diberi arti sebagai suatu proses untuk menginteraksikan antara kayu sebagai benda kerja dengan alat potong, yang sumberdaya atau penggerak bagi alat potong itu berasal dari mesin bermotor listrik, sedemikian rupa sehingga benda kerja kayu tersebut itu pada akhir proses interaksi itu akan memiliki bentuk, ukuran, dimensi, presisi dan tingkat kehalusan tertentu pada permukaannya.

Dengan demikian, maka Pengerjaan Kayu merupakan terminologi yang digunakan untuk menginformasikan mengenai proses pemotongan kayu yang dilakukan dengan menggunakan alat potong tradisional yang sudah barang tentu terutama lebih banyak mengandalkan ketrampilan para pekerja atau tukang kayu. Beberapa contoh alat tradisional kayu yang dimiliki dalam khasanah budaya Jawa adalah "Pethel", "Wadhung", "Dhandang", "Kapak" dan "Pasah", serta "Tatah".

Sementara itu, Pemesinan Kayu merupakan terminologi yang $\mathrm{d}$ i g u n a $\mathrm{k}$ a $\mathrm{n} n \mathrm{t} u \mathrm{k}$ menginformasikan mengenai proses pemotongan kayu yang dilakukan dengan menggunakan alat potong moderen, yang sumber daya penggerak utama terhadap alat potong tersebut berasal dari mesin yang dilengkapi dengan motor listrik sebagai tenaga penggeraknya. Mesin tangan penyerut (planer), mesin tangan pembentuk (moulder), mesin tangan peraut (router), mesin tangan penatah (carver), mesin tangan pembor (boring machine) merupakan beberapa mesin tangan moderen yang dapat disebut sebagai contoh.

Apabila usulan penulis ini diterima, maka Pengerjaan Kayu merupakan diksi (pilihan terminologi) yang ditujukan untuk menginformasikan mengenai pemotongan kayu dengan menggunakan peralatan tradisional. Sementara itu, Pemesinan Kayu merupakan diksi yang ditujukan untuk menginformasikan mengenai pemotongan kayu yang dilakukan dengan menggunakan peralatan moderen yang ditandai dengan motor listrik sebagai tenaga penggerak alat pemotong kayu yang dimaksud. 
Untuk dapat memahami secara lebih detail mengenai perbedaan di antara kedua istilah tersebut dan pengaruhnya terhadap kayu, maka bahasan mengenai analisis pemotongan kayu perlu disajikan. Penyajiannya dikemas di dalam sub-bab berikut.

Analisis pemotongan kayu dengan peralatan tradisional dan peralatan moderen

Dalam proses pemotongan kayu, "benda kerja awal" yang berupa kayu diinteraksikan dengan alat pemotong. Interaksi antara kayu dan alat pemotong itu berlangsung sedemikian rupa sehingga benda kerja kayu sebagai bahan awal atau bahan mentah tadi berubah status menjadi kayu sebagai "barang-jadi". "Barang-jadi" ini memiliki bentuk dan dimensi (ukuran dalam hal: panjang, lebar, tebal) tertentu, yang berbeda dibandingkan dengan "benda kerja awal" tadi. Sudah barang tentu, kayu sebagai "benda jadi" ini memiliki dimensi yang lebih kecil dibandingkan dengan dimensi kayu ketika dirinya masih berstatus sebagai "benda kerja awal".

Sesuai dengan rancangan dalam membangun suatu struktur bangunan, kayu sebagai "barang jadi" tersebut diorientasikan untuk memiliki keragaman dalam hal bentuk dan dimensinya. Sesuai dengan bentuk dan dimensinya, masing-masing kayu sebagai "barang-jadi" tadi kemudian berstatus sebagai komponen tertentu di dalam suatu sistem yang membentuk suatu konstruksi bangunan. Masing-masing "barang jadi" kayu ini ada yang berstatus sebagai: tiang, belandar, usuk, reng, papan dinding, kusen, daun pintu, daun jendela, julasi dan lain sebagainya.

Di samping diperoleh "barang jadi" kayu sebagai benda utama, di dalam proses pemotongan kayu ini juga dihasilkan hasil sampingan, yang sering disebut limbah. Ada banyak nama yang diberikan terhadap limbah ini, bergantung pada bentuk dan ukurannya. Limbah ini ada yang disebut tatal, ada yang disebut serbuk, ada pula yang disebut serpih, bahkan ada pula yang disebut sebetan.

$\mathrm{D}$ a $\mathrm{l}$ a $\mathrm{m} \quad \mathrm{r}$ a $\mathrm{n} \mathrm{g} \mathrm{k}$ a mempermudah pemahaman kita mengenai perbedaan antara pemotongan kayu dengan alat tradisional dan alat moderen, maka akan dibandingkan dua alat yang memiliki fungsi sama. Satu dari dua alat itu mewakili peralatan tradisional, sedangkan satu lainnya mewakili peralatan moderen. Untuk kepentingan itu, dipilih pasah dan penyerut. Pasah sebagai wakil dari peralatan tradisional, sedangkan penyerut (planer) sebagai wakil dari alat moderen. Keduanya memiliki fungsi yang sama, yaitu untuk memperhalus permukaan kayu.

Sebagai sebuah alat tradisional, Pasah memiliki lima komponen alat. Kelima komponen tersebut meliputi 1 . sebilah mata pisau utama, 2. sebilah mata pisau pendukung, 3. kancing pisau, 4. unduk (kerangka pasah), dan 5. tuas kemudi (setang). Untuk memperhalus permukaan kayu, pasah digunakan dengan cara menempelkan pasah itu pada permukaan kayu yang akan diperhalus. Melalui tuasnya, pasah ini kemudian ditekankan pada permukaan kayu, sembari mendorong pasah tersebut agar meluncur pada permukaan kayu. Menurut Koch (1964), gaya tekan yang ditimbulkan oleh pasah pada permukaan kayu disebut gaya normal, sementara itu, gaya dorong yang membuat pasah itu meluncur pada permukaan kayu disebut gaya paralel.

Dengan kedua jenis gaya yang bekerja secara serentak itu, mata pisau pada pasah akan mengiris kayu dengan kedalaman tertentu. Kedalaman ini relatif sama sejak awal persentuhan antara mata pisau dengan kayu sampai dengan akhir persentuhan antara keduanya. Dengan kata lain, sejak awal persentuhan antara pasah dan kayu sampai dengan akhir persentuhan keduanya, mata pisau yang hanya sebilah pada pasah itu akan mengiris kayu dengan kedalaman yang sama. Hal ini disebabkan karena persatuan pisau dengan permukaan kayu tersebut berlangsung secara terusmenerus, bersinambung dan intim. Oleh karena itu, irisan ini akan menghasilkan limbah berupa serpih yang panjang bersinambung dan tak terputus-putus serta memiliki ketebalan yang sama dari ujung awal serpih sampai dengan ujung akhir serpih. Serpih yang merupakan irisan kayu yang teruntai secara panjang ini disebut serutan (Suranto, 2007).

Apabila sisi iris pisau dalam kondisi tajam, sudut pisau diatur secara tepat dan kedalaman irisan yang wajar (tidak terlalu dalam tetapi juga tidak terlalu dangkal), maka serpih yang panjang tak terputus tadi sekaligus menghasilkan bidang iris yang halus. Bidang iris ini merupakan bidang datar dan sebagai permukaan baru yang halus pada kayu yang berstatus sebagai "barang jadi". Proses pengirisan yang terdapat di dalam mekanisme pemotongan demikian disebut proses pemotongan ortogonal (Koch, 1964).

Uraian di atas merupakan penyajian tentang mekanisme pemotongan yang dilakukan oleh 
pasah sebagai sebuah peralatan tradisional. Uraian berikut menyajikan informasi tentang mekanisme pemotongan yang dilakukan oleh penyerut sebagai sebuah peralatan moderen.

Sebagai sebuah peralatan moderen, penyerut memiliki sembilan bagian mesin, yaitu 1. kerangka mesin, 2. motor listrik, 3. sabuk transmisi daya, 4. kepala potong, 5 . mata pisau yang berjumlah minimum dua bilah, bahkan ada yang berjumlah 8 bilah, 6. pengunci pisau pada kepala potong, 7. sakelar (tombol) untuk menghidup-matikan motor listrik, 8. handel atau pemegang dan 9 . pelindung sabuk transmisi (Suranto, 2006).

Mekanisme kerja penyerut adalah sebagai berikut. Motor listrik yang terdiri atas stator dan rotor, maka rotor akan berputar pada porosnya sebagai akibat adanya aliran arus listrik. Daya putar rotor ini dipindahkan dari motor listrik menuju kepada kepala potong. Pemindahan dilakukan oleh sistem transmisi yang pada umumnya berupa sabuk atau pita. Oleh karena pemindahan daya putar ini, kepala potong mengalami perputaran pada porosnya. Mengingat bahwa kepala potong ini merupakan tempat bersemayam banyak pisau, maka perputaran kepala potong ini juga akan mengakibatkan perputaran banyak pisau seirama dengan berputarnya kepala potong. Banyak pisau yang terputar ini akan mengakibatkan masing-masing sisi iris pisau (bagian tajam pada pisau) akan bersentuhan dengan permukaan kayu. Persentuhan ini akan mengakibatkan pengirisan kayu. Karena persentuhan antara masing-masing pisau dengan permukaan kayu tersebut hanya berlangsung secara sesaat atau sekejap, maka pengirisan kayu oleh masing-masing pisau juga hanya berlangsung secara sesaat atau sekejap (Suranto, 2006).

Secara lebih detil, proses pengirisan kayu dapat dijelaskan sebagai berikut. Pisau pertama datang menyentuh kayu secara sekejap, sehingga pisau memerankan fungsi pengirisan kayu juga berlangsung secara sekejap. Hal ini disebabkan karena setelah menyentuh permukaan kayu, pisau pertama tadi segera pergi menjauh dan meninggalkan kayu. Sikap pisau yang demikian ini disebabkan karena pisau ini terbawa oleh kepala potong yang berputar. Kepergian pisau pertama dari permukaan kayu segera disusul dengan kedatangan pisau kedua pada permukaan kayu. Kedatangan dan persentuhan antara pisau kedua dengan permukaan kayu ini juga hanya berlangsung secara sekejap, sehingga mengakibatkan pengirisan kayu yang akan berlangsung secara sekejap pula. Pola persentuhan dan pengirisian terhadap kayu yang diperankan oleh pisau pertama dan pisau kedua itu juga diikuti oleh pisau ketiga dan pisau-pisau berikutnya (Kollmann and Cote, 1968).

Dengan demikian, proses pengirisan yang dilakukan oleh masing-masing pisau hanya berlangsung secara sekejap. Meskipun sekejap, pengirisan oleh masing-masing pisau ini berlangsung secara berulang kali, karena masing-masing pisau tersebut dibawa oleh kepala potong yang berputar. Pengirisan yang berlangsung secara sekejap tetapi berlangsung secara berulang kali itu secara akumulatif akan membentuk bidang irisan yang berupa bidang datar. Apabila dicermati secara detil, bidang yang dihasilkan ini bukanlah merupakan bidang yang sungguhsungguh datar, melainkan bidang yang bergelombang, meskipun masing-masing gelombang tersebut berukuran sangat kecil. Masingmasing gelombang ini dibentuk oleh tapak-tapak pisau ketika masingmasing pisau tersebut menyentuh dan mengiris kayu. Oleh karena itu, bidang datar hasil proses pengirisan akan terasa kasar (Kollman and Cote, 1968). Serpih yang dihasilkan dalam proses pemotongan ini berupa tatal yang jumlahnya sangat banyak. Masing-masing tatal ini berukuran kecil dan pendek. Proses pengirisan yang terdapat di dalam mekanisme pemotongan demikian oleh Koch (1964) disebut proses pemotongan periferi.

Dengan membandingkan antara pasah dan penyerut moderen sebagaimana dipapar di atas, terlihat bahwa masing-masing alat itu saling berbeda dalam hal mekanisme dan proses pemotongannya. Apabila dilakukan generalisasi, pasah yang mewakili peralatan tradisional dan penyerut yang mewakili peralatan moderen, maka dapat disimpulkan bahwa peralatan tradisional sangat berbeda terhadap peralatan moderen, baik dalam hal proses pemotongan, mekanisme pemotongan, hasil pemotongan dan jenis limbah yang dihasilkannya. Secara anatomis, proses pemotongan dengan menggunakan peralatan tradisional disebut pemotongan ortogonal, sedangkan proses pemotongan dengan menggunakan peralatan moderen sebagian besar disebut pemotongan periferi. Mekanisme pemotongan pada peralatan tradisional dilakukan hanya oleh sebilah alat potong yang mengiris secara terus-menerus dan sinambung pada sepanjang permukaan kayu, sedangkan pada peralatan moderen, pengirisan dilakukan oleh banyak alat potong yang mengiris secara bergantian dan masing-masing pengirisan 
berlangsung secara sekejap. Hasil pemotongan pada peralatan tradisional berupa satu bidang yang lurus dan datar berpermukaan datar, sedangkan pada peralatan moderen berupa bidang yang bergelombang. Jenis limbah yang dihasilkan pada peralatan tradisional berupa tatal yang panjang dan memiliki ketebalan sama dari bagian awal tatal hingga bagian akhir tatal, sedangkan pada peralatan moderen, limbah itu berupa serpih-serpih kecil yang pendek dan ketebalan yang tidak sama dari bagian awal, bagian tengah dan bagian akhir serpih.

Mengingat kedua jenis pemotongan ini terbukti berbeda, maka proses pemotongan dengan peralatan moderen akan memberikan pengaruh yang berbeda secara nyata dibandingkan dengan pemotongan yang dilakukan dengan peralatan tradisional. Berbagai jenis pengaruh proses pemotongan dengan peralatan moderen atau pengaruh proses pemesinan kayu akan diperikan di dalam sub-bab berikut.

Pengaruh proses pemesinan terhadap kayu

Pengaruh proses pemesinan atau penggunaan alat moderen pada kayu dapat dipilah menjadi tiga butir. Secara berurutan, pengaruh itu berupa daya pukul, daya panas dan kekasaran permukaan kayu setelah diiris. Masing-masing pengaruh itu diperincikan sebagai berikut.

Pengaruh proses pemesinan terhadap kayu pertama-tama berupa pengaruh daya pukul yang dilakukan oleh setiap pisau pemotong terhadap kayu. Dari mekanisme pemotongan periferi sebagaimana dipaparkan pada uraian di depan, diketahui bahwa setiap bilah pisau yang dibawa oleh kepala potong yang berputar itu akan menyentuh permukaan kayu, melakukan proses pengirisan secara sekejap, kemudian pergi meninggalkan kayu. Interaksi antara masing-masing bilah mata pisau dengan kayu ini akan menimbulkan efek pemukulan kepada kayu oleh masing-masing mata pisau tersebut. Karena proses pemotongan ini melibatkan banyak bilah mata pisau dan masing-masing pisau menyentuh kayu secara berulang-ulang, maka efek pemukulan oleh mata pisau ini kepada kayu secara akumulatif juga berlangsung secara berulang-ulang. Pemukulan ini sudah tentu akan mengurangi kekuatan kayu dan memperlemah kayu tersebut.

Pengurangan kekuatan akan semakin besar seirama dengan semakin lamanya proses pemotongan berlangsung. $\mathrm{Hal}$ itu disebabkan karena semakin lama berlangsungnya proses pemotongan, semakin menumpulkan sisi iris pisau. Pisau yang semakin tumpul akan menimbulkan efek pemukulan yang semakin besar kepada kayu. Bila kayu yang dimesin ini memiliki kekuatan yang rendah, maka kayu tersebut dapat mengalami retak, pecah, terbelah bahkan hancur. Di samping disebabkan oleh proses penumpulan pisau, tingkat pengurangan kekuatan kayu juga disebabkan oleh tingkat kedalaman pisau ketika memotong kayu. Pengurangan kekuatan kayu akan semakin besar seiring dengan semakin dalamnya ujung pisau masuk ke dalam tubuh kayu. Hal ini disebabkan karena kedalaman proses pemotongan akan mengakibatkan daya benturan yang semakin besar pula antara pisau dengan kayu.

Pengaruh yang kedua proses pemesinan terhadap kayu akan berupa peningkatan suhu pada permukaan kayu, sehingga permukaan kayu menjadi panas. Peningkatan suhu atau derajat panas ini merupakan akibat logis dari adanya daya pukul masing-masing pisau pemotong terhadap permukaan kayu. Bila sisi iris pisau semakin tumpul atau semakin majal (semakin tidak tajam lagi), pemotongan dilakukan semakin tebal yang tandai dengan semakin dalamnya pisau masuk ke dalam kayu, dan putaran kepala potong semakin tinggi yang ditandai dengan rpm (rotation per minute) yang semakin tinggi, maka permukaan kayu hasil pemotongan akan menjadi semakin panas. Pada kondisi tertentu, permukaan kayu bisa menjadi sangat panas. Sangatlah sering kali terjadi bahwa suhu yang semakin tinggi dan menjadi sangat tinggi akan mengakibatkan warna permukaan kayu menjadi menghitam karena hangus terbakar.

Pengaruh yang ketiga proses pemesinan terhadap kayu akan berupa kekasaran pada permukaan kayu sebagai hasil proses pemotongan. Dengan kata lain, rendahnya tingkat kehalusan pada pemukaan kayu sebagai hasil proses pemotongan bila pemotongan dilakukan dengan menggunakan peralatan moderen. Kekasaran permukaan kayu merupakan suatu keniscayaan pada permukaan kayu yang dihasilkan dari proses pemotongan secara ortogonal. Hal ini disebabkan karena bidang potong tersebut merupakan deretan yang tersusun atas tapak-tapak pisau pada permukaan kayu dan masingmasing tapak ini memiliki bentuk yang cekung atau juring. Bahkan bila ada satu saja pengaturan yang tidak tepat dalam beberapa hal yang 
berkait dengan: pengaturan sudut pisau, atau kedalam sisi iris, atau kecepatan putar, atau kecepatan pengumpanan, maka permukaan kayu tidak hanya mengalami kekasaran permukaan, tetapi juga akan mengalami cacat pemesinan pada permukaan kayu. Ada berbagai macam cacat pemesinan yang menjadikan permukaan kayu menjadi sangat kasar. Cacat-cacat permesinan kayu dapat berupa serat tercabik, serat terserpih, serat terangkat dan serat berbulu yang terdapat pada permukaan kayu (Koch, 1964).

Secara keseluruhan, penggunaan alat moderen dalam proses pemesinan kayu tidak hanya berpengaruh terhadap kayu saja, tetapi juga berpengaruh terhadap peralatan moderen yang digunakan, bahkan pengaruh itu semakin nyata pula terhadap pekerja atau orang yang mengoperasikan mesin pemotong kayu tersebut. Hal yang terakhir ini terjadi mengingat pekerjalah yang mengatur proses pengumpanan kayu terhadap peralatan moderen. Dengan kata lain, pekerjalah yang menentukan proses penginteraksian antara kayu dan alat moderen mesin pemotong kayu.

Keniscayaan penerapan teknologi pengerjaan kayu secara tradisional

Undang-undang No. 5 tahun 1992 tentang Benda Cagar Budaya yang mulai diberlakukan pada tanggal 21 Maret 1992 memuat tiga pertimbangan. Dua pertimbangan di antaranya yaitu (1) Benda Cagar Budaya merupakan kekayaan budaya bangsa yang penting artinya bagi pemahaman dan pengembangan sejarah, ilmu pengetahuan dan kebudayaan, sehingga perlu dilindungi dan dilestarikan, demi pemupukan kasadaran jatidiri bangsa dan kepentingan nasional, (2). Untuk menjaga kelestarian benda cagar budaya, diperlukan langkah pengaturan bagi penguasaan, pemilikan, penemuan, pencarian, perlindungan, pemeliharaan, pengelolaan, pemanfaatan dan pengawasan benda cagar budaya. Upaya perlindungan dan pemeliharaan benda cagar budaya ditegaskan di dalam Bagian IV pasal 13 ayat 2 . Pasal 13 ayat 2 ini mengamanatkan, bah wa perlindungan dan pemeliharaan benda cagar budaya wajib dilakukan dengan memperhatikan nilai sejarah dan keaslian bentuk serta pengamanannya.

Dari pasal 13 ayat 2 tersebut, tersurat bahwa perlindungan dan pemeliharaan sebagai upaya pelestarian benda cagar budaya wajib dilakukan dengan memperhatikan nilai sejarah dan keaslian bentuk. Dengan demikian, keaslian bentuk atau orisinalitas bentuk merupakan hal yang maha penting bagi pelestarian benda cagar budaya, sehingga orisinalitas tidak dapat ditawar lagi.

Upaya pelestarian benda cagar budaya dilakukan antara lain dengan cara perlindungan, pemeliharaan, perawatan baik secara preventif maupun kuratif, pengawetan (pengkonservasian) dan pemugaran. Perawatan secara kuratif dilakukan dengan kegiatan pembersihan, perbaikan dan konsolidasi terhadap benda-cagar budaya. Sementara itu, pemugaran benda cagar budaya, yang di dalam aktivitas pemugaran ini dimungkinkan adanya penggantian dengan komponen "baru" terhadap komponen penyusun benda cagar budaya yang mengalami kerusakan. Penggantian dengan komponen baru tersebut sudah barang tentw juga dilakukan dengan mempertahankan orisinalitasnya. Prinsip orisinalitas mengandung arti bahwa keaslian dalam hal bahan, teknologi cara mengerjakan komponen benda cagar budaya, bentuk benda cagar budaya, dan struktur benda cagar budaya wajib dipertahankan di dalam aktivitas pemugaran benda cagar budaya.

Dari uraian di atas, dapat disimpulkan bahwa upaya pemugaran benda cagar budaya berbahan kayu niscaya dilakukan dengan menjaga orisinalitasnya, tidak terkecuali juga orisinalitas dalam hal teknologi cara mengerjakan kayu sebagai komponen penyusun benda cagar budaya. Di dalam konteks menjaga orisinalitas teknologi pengerjaan kayu, terbukti bahwa pengerjaan kayu secara tradisional wajib dilakukan di dalam rangka mempersiapkan pengganti komponen benda cagar budaya. Selain disebabkan oleh amanat yang ditentukan di dalam Undangundang nomor 5 tahun 1992 tentang Benda Cagar Budaya, cara mengerjakan kayu secara tradisional ini juga tidak dapat digantikan oleh cara pengerjaan kayu secara moderen, mengingat bahwa cara mengerjakan kayu secara tradisional berbeda secara nyata terhadap cara mengerjakan kayu secara moderen. Sebagaimana disebutkan, perbedaan antara keduanya terwujud dalam lima hal, yaitu: proses pemotongan, mekanisme pemotongan, hasil pemotongan dan jenis limbah yang dihasilkan, serta efek yang diderita oleh kayu sebagai akibat proses pemotongan.

\section{Implikasi dan konsekuensi}

Berdasarkan pada beberapa 
argumentasi sebagaimana dipaparkan di atas, maka upaya untuk mempertahankan orisinalitas benda cagar budaya di dalam proses pemugarannya, khususnya berkait dengan keaslian teknologi pengerjaan kayu secara tradisional, akan menghadirkan implikasi dan konsekuensi tertentu. Beberapa butir implikasi yang menyertainya dan perlu diusahakan perwujudannya adalah sebagai berikut. 1. Mempertahankan keberadaan empu-kayu atau maestro-kayu, yakni tukang kayu yang piawai,baik dalam mengoperasikan berbagai jenis peralatan dengan teknologi pengerjaan kayu secara tradisional, maupun dalam menghasilkan produk kayu jadi yang berkualitas tinggi. 2. Meningkatkan jumlah empu kayu dan mengusahakan persebarannya secara merata di seluruh wilayah nusantara, mengingat banyaknya jumlah benda cagar budaya berbahan kayu yang perlu dipugar dan luasnya persebaran benda cagar budaya tersebut di seluruh wilayah nusantara. 3. Melakukan regenerasi empu-kayu agar upaya pelestarian benda cagar budaya dapat dilakukan pada periode waktu kapan pun seiring dengan proses perguliran waktu. Sementara itu, konsekuensi yang muncul sebagai tanggapan atas implikasi di atas adalah sebagai berikut. 1. Melakukan inventarisasi terhadap empu-kayu dan memberikan sertifikasi atas kemampuan dan kopetensinya dalam mengerjakan komponen bangunan yang berstatus sebagai benda cagar budaya, serta memberikan jaminan kecukupan kebutuhan hidup kesehariannya. 2 . Melakukan proses pendidikan dan pelatihan dari para empu-kayu itu kepada para calon empu-kayu dengan model magang (yang dalam bahasa jawa disebut "nyantrik"), sehingga jumlah empu-kayu dapat ditingkatkan dan regenerasi empukayu dapat dilakukan dan dipertahankan.

Upaya untuk mengelaborasi terhadap hal-hal yang termaktub di dalam implikasi dan konsekuensi di atas, merupakan hal yang pelik. $\mathrm{Di}$ dalam suasana interaksi politik antara pemerintah pusat dan pemerintah daerah yang ditandai dengan pola desentrasilasi dan otonomi daerah, upaya untuk mewujudkan pelestarian benda cagar budaya perlu dipikirkan secara bersama dan disinergikan di antara kementerian Departemen Kebudayaan dan Pariwisata, instansi-instansi Balai Pelestari Peninggan Purbakala (BP3), dinasdinas kebudayaan dan pariwisata pada berbagai level pemerintah daerah / kota dalam rangka berbagi peran dalam upaya pelestarian. Dalam konteks ini, upaya pencarian sistem pembagian peran untuk menemukan pola sistem sosial di dalam upaya pelestarian benda cagar budaya berbahan kayu dapat dilakukan dengan dialog intensif yang melibatkan seluruh institusi tersebut di atas. Bila diperlukan, upaya itu dapat didukung dengan melakukan studi pada negara maju tertentu yang terbukti piawai di dalam pelestarian $\mathrm{BCB}$ berbahan kayu.

Pada negara maju dan piawai di dalam mengkonservasi benda cagar budaya berbahan kayu sebagai warisan generasi nenekmoyang, semisal negara Jepang, telah terwujud suatu sistem institusi dan sistem sosial yang memungkinkan untuk mempertahankan jumlah dan kualitas para empu-kayu serta proses regenerasinya dan sisitem itu dapat berfungsi secara sangat baik. Oleh karena itu, perlindungan dan pelestarian terhadap benda cagar budaya berbahan kayu dapat dilakukan dengan hasil yang gemilang. Houryuji Temple, sebagai sebuah benda cagar budaya berbahan kayu yang dibangun pada abad ke tujuh dengan tiang-tiangnya yang diambil dari pohon berusia 350 tahun (Imamura, 2009), sekarang masih berdiri secara megah. Kondisi Houryuji Temple yang demikian ini merupakan salah satu bukti atas kegemilangan prestasi Negara Jepang di dalam melestarikan benda cagar budaya berbahan kayu. Oleh karena itu, negara ini dapat dipilih sebagai medan pembelajaran dalam upaya mencari model bagi pelestarian benda cagar budaya berbahan kayu milik kita.

\section{Daftar Pustaka}

Anonim, 1992. Undang-Undang no 5 tabun 1992 tentang Benda Cagar $B \quad u \quad d \quad a \quad y \quad a$. Http://www.theceli.com/docu men/produk/1992/UU5-1992 diunduh 9 November 2009.

Imamura, Yoji. 2009. Komunikasi pribadi pada 2 November 2009. I P B International Conference Center, Bogor.

Koch, P. 1964. Wood Macbining Processes. The Roonald Press Company. New York.

Kollman F.F.P., and Cote, W.A., 1968. Principle of Wood Science and Tecbnology. L'olume I. Solid Wood. Springer-Verlag. New York Incorporation.

Suranto, Y. 2006. Baban Kuliab Mesinmesin Industri Hasil Hutan. Jurusan Teknologi Hasil Hutan. Fakultas Kehutanan Universitas Gadjah Mada. Yogyakarta.

Suranto, Y. 2007. Baban Kuliab Pemesinan Kayu. Jurusan Teknologi Hasil Hutan. Fakultas Kehutanan Lniversitas Gadjah Mada. Yogvakarta. 